\title{
ALTERNATIVE METHODS IN THE CONTROL OF THE TWO SPOTTED SPIDER MITE, TETRANYCHUS URTICAE KOCH ( ACARI: TETRANYCHIDAE) ON SOYBEAN PLANTS
}

\author{
H. A. Taha, A. I. Amer and Heba M. Nasr \\ Plant Protection Research Institute, Agriculture Research Centre, Dokki, Giza, Egypt
}

Received: Apr. 23, 2019

Accepted: Apr. 30, 2019

\begin{abstract}
Soybean (Glycine max L.) has received special attention all over the world because of the great nutritive and oil values of its seeds. The spider mite, Tetranychus urticae Koch considered one of the main pests, which threatens the soybean crop yield. Three field experiments were conducted during the season, 2017 at Kafriklaa, El-Santta district, Gharbia Governorate, to evaluate some environmentally safe materials; some plant extracts and the efficiency of the predatory mite, Phytoseiulus persimilis (A.-H.) in controlling the two spotted spider mite, $T$. urticae infesting soybean.
\end{abstract}

Obtained results showed that mixture of Vertimec + Super-Misrona oil exhibited the highest reduction (94.4\%) followed by Vertimec + Micro-elements (92.2\%), Vertimec alone (88.55\%), Super-Misrona oil + Micro-elements (78.2\%), Super-Misrona alone (75.4\%) and Liquid-Sulphur (70.8\%).

The efficacy of the three plant extracts could be arranged in a descending order as follows: 68.7, 62.7 and $57.2 \%$ for Oshar (Calotropis procera Ait), Black shadenight (Solanium nigrium L.) Unrip- fruit and Neem (Azadirachta indica A. Juss) extracts. The third trail was releasing the predatory mite, $P$. persimilis with rate of 15-20 mites/hill during seedling stage of soybean plants and the level infestation 3-5 mites/plant. The population of spider mites reduces $71.5 \%$ after 8 weeks of releasing and the level of infestation had become under threshold for the end of season.

Key words : Biological control, botanical pesticides, phytophagous mites

\section{INTRODUCTION}

Soybean is considered one of the relatively new crops introduced into the Egyptian Agricultural 1960, which contribute in reducing food deficiency gap for high quality ratio of protein and oil contained in its seeds reaching up to $40 \%$ as well as approximately $20 \%$ of oil. A phenomenal increase in soybean cultivation during the period of 19801990, whereas more than hundred and fifty thousands Feddans were cultivated, while this area decreased during the last two decades because of some problems of marketing and manufacture. The spider mite, $T$. urticae (Acari : Tetranychidae) cause a great damage such as tiny yellow, brown or bronze and finally die and drop off. Soybean plants injured by mites early have increased shattering produce smaller and wrinkled seeds. Early and severe mite infestation left untreated can completely element and reduce soybean yield (Taha et al., 2002). Baker and Connel (1963) mentioned that spider mites damaged protective leaf surface and stoma and it might inject toxic substances into the leaf and interfere with vital processes. Recently, there is a great interest in the use of alternative methods for controlling pests infesting different crops, because of the extensive use of pesticides, which play dangerous role for human health, environmental pollution, more over different pests acquired resistance to pesticides as well as the use of the biological control agents in pest control. 
The present study aims to throw light on some alternative safety materials to suppress the population of the two spotted spider mite, Tetranychus urticae on soybean plants, as well as to evaluate the efficiency of the predatory mite, Phytoseiulus persimilis in its control at Gharbia Governorate.

\section{MATERIALS AND METHODS}

An area of 1.5 Feddan $\left(6300 \mathrm{~m}^{2}\right)$ was cultivated with soybean (Glycine max), variety Giza 21 at the village Kafriklla, ElSantta district, Gharbia Governorate on May, 20, 2017. This area was $210 \mathrm{~m}$ long, $30 \mathrm{~m}$ wide, with 42 rows of $70 \mathrm{~cm}$ width, $25 \mathrm{~cm}$ between hills, two plants for each hill by two sides. A row left unseeded as a buffer between replicates. Normal agricultural practices were done during the season.

This area was divided into three experiments:

The first experiment:

An area of $2850 \mathrm{~m}^{2}(30 \times 95 \mathrm{~m})$ was divided into 32 plots each of about ( $7.5 \mathrm{X}$ $11.8 \mathrm{~m}=89 \mathrm{~m}^{2}$ ).

These compounds were sprayed to evaluate their effects on $T$. urticae :

1. Vertimec $1.8 \%$ EC (V), with rate of 40 $\mathrm{ml} / 100 \mathrm{~L}$. water.

2. Super-Misrona oil $95 \%$ EC (SMO), with the rate of $1 \%$.

3. Liquid-Sulphur $52 \%$ EC (LS), with rate of $250 \mathrm{ml} ' 100 \mathrm{~L}$. water.

4. Micro-Elements (ME) (Fe, Mn, Zn \& Cu), with rate of $150 \mathrm{ppm}$.

5. $V+S M O$, with rate of $40 \mathrm{ml}+1 \%$.

6. $V+M E$, with rate of $40 \mathrm{ml}+150 \mathrm{ppm}$.

7. SMO + ME, with rate of $1 \%+150 \mathrm{ppm}$.

8. Control.

The second experiment:

An area of $1350 \mathrm{~m}^{2}(30 \times 45 \mathrm{~m})$ was divided into 12 plots each of $112.5 \mathrm{~m}^{2}$.

Three plant extracts were sprayed on soybean plants to evaluate their effects on T. urticae :
1- Oshar plant (Calotropis procera Ait) was obtained from Aswan Governorate; leaves dried, grounded, $250 \mathrm{~g}$ of powder were successive extracted with ethanol solvent. The Oshar extract was used with rate of $50 \mathrm{ml} \mathrm{I} \mathrm{10L,} \mathrm{water.} \mathrm{Freedman} \mathrm{et}$ al(1979) extract Oshar with different solvents varied in their polarity i.e. hexane, ethanol, petroleum ether and water.

2- Black nightshade, Solanium nigrium L. the fresh unripe fruits $(1 \mathrm{~kg})$ were extracted by macerations in water for $\mathbf{1 5}$ min during stirring and then filtered (Karawaya and Abd-El-Wahab, 1975).

3- Neem extract Azadirachta indica A. Juss.(Azadirachtin $\quad 40 \% \quad$ EC). Application rate was $50 \mathrm{ml} / 10 \mathrm{~L}$ water, the commercial formulated was obtained from Agriculture company in Egypt.

The third experiment:

Utilizing the predatory mite, Phytoseiulus persimilis in controlling $T$. urticae on soybean plants.

Mass production of the predator mites on common bean plants (Phaseolus vulgaris L.) planted in net plastic greenhouses. An area of 1/2 Feddan $\left(2100 \mathrm{~m}^{2}\right)(30 \times 70 \mathrm{~m})$ of soybean plants was divided into five plots $A, B, C, D$ and untreated one as control, each of $420 \mathrm{~m}^{2}$ (6X70 m).

The predator mites released by $\mathbf{1 5 - 2 0}$ individuals/plant during seedling stage, when infestation level was 3-5 mites/plant. Infestation was carried out weekly; count the motile stages of spider mites using stereomicroscope, while the number of predators observed at the field by $20 \mathrm{X}$ hand lens.

All treatments were replicated three times and arranged as a complete randomized block design.

For the first and second experiments, the motile stages of spider mites were counted in two sq. inches lower surfaces 
Alternative methods in the control of the two spotted spider mite,

of 20 leaflets/plot $\quad(160 \quad$ sq inches/treatments) using stereomicroscope at laboratory.

The investigation was carried out directly before spraying and after 3, 7, 14 and 21 days of spraying.

Henderson and Tilton (1955) equation was used to determine mortality percentages.

\section{RESULTS AND DISCUSSION}

\section{Evaluation of safe} compounds singly and in combination against spider mite, T. urticae on soybean plants in Gharbia Governorate during the season, 2017:

As shown in Table (1) data revealed that all tested compounds exhibited high

mortality after three days of treatment, whereas V + SMO exhibited the highest activity (96.5\%) followed by $\mathrm{V}+\mathrm{ME}$ (94.9\%), V. alone (92.7\%), SMO+ME (82.8\%), SMO alone (81.5\%), L.S. (78.9\%) and ME (51.5\%) respectively.

Overall reduction percentages of the tested compounds, could be arranged in a descending order as follows: 94.4, 92.2, 88.55, 78.2, 75.4, 70.8 and $42.5 \%$ for the above mentioned V.+ SMO, V.+ME,V., SMO+ME, SMO and LS respectively .

Data showed that micro-elements were the lowest mortality percentages (51.5, 45.7, 43.6 \& 29.0) with a general mean $42.5 \%$, but on the other hand, ME improved plant health and crop yield. These results are agreement with those obtained by Masis and Aguilar (1990), Botha et al. (1994) and Omar et al. (2000).

Table (1): Mite numbers and reduction \% of the tested safe materials against $T$. urticae on soybean plants in Gharbia Governorate during the season 2017

\begin{tabular}{|c|c|c|c|c|c|c|c|c|c|c|}
\hline \multirow{3}{*}{$\begin{array}{l}\text { Treatments \& } \\
\text { application } \\
\text { rate }\end{array}$} & \multirow{3}{*}{$\begin{array}{l}\text { mite no. } \\
\text { pre- } \\
\text { treatment }\end{array}$} & \multicolumn{8}{|c|}{ No. of mites /160 sq. inches \& Reduction \% after : } & \multirow{3}{*}{$\begin{array}{c}\text { Over all } \\
\text { red\% }\end{array}$} \\
\hline & & \multicolumn{2}{|c|}{3 days } & \multicolumn{2}{|c|}{7 days } & \multicolumn{2}{|c|}{14 days } & \multicolumn{2}{|c|}{21 days } & \\
\hline & & No. & $\%$ & No. & $\%$ & No. & $\%$ & No. & $\%$ & \\
\hline $\begin{array}{c}\text { V+SMO } \\
40 \mathrm{ml}+1 \%\end{array}$ & 556 & 18.0 & 96.9 & 29.0 & 95.1 & 38.0 & 93.8 & 45.0 & 91.7 & 94.4 \\
\hline $\begin{array}{c}\text { V+ME } \\
40 \mathrm{ml} / 100 \mathrm{~L} \\
\mathrm{w}+150 \mathrm{ppm}\end{array}$ & 584 & 31.0 & 94.9 & 42.0 & 93.3 & 55.0 & 91.5 & 66.0 & 88.4 & 92.2 \\
\hline $\begin{array}{c}V \\
40 \mathrm{ml}\end{array}$ & 590 & 45.0 & 92.7 & 56.0 & 91.1 & 82.0 & 87.5 & 98.0 & 82.9 & 88.55 \\
\hline $\begin{array}{c}\text { SMO+ } \\
\text { ME } \\
1 \%+150 \mathrm{ppm} \\
\end{array}$ & 602 & 108.0 & 82.8 & 128.0 & 80.0 & 155.0 & 76.8 & 156.0 & 73.4 & 78.2 \\
\hline $\begin{array}{c}\text { SMO } \\
1 \%\end{array}$ & 654 & 121.0 & 81.5 & 138.0 & 80.4 & 185.0 & 74.5 & 220.0 & 65.0 & 72.4 \\
\hline $\begin{array}{c}\text { LS } \\
250 \mathrm{ml} / 100 \\
\mathrm{Lw}\end{array}$ & 648 & 142.0 & 78.9 & 185.0 & 73.2 & 226.0 & 68.6 & 236.0 & 62.7 & 70.8 \\
\hline $\begin{array}{c}\text { ME } \\
150 \text { ppm }\end{array}$ & 566 & 285.0 & 51.5 & 328.0 & 45.7 & 354.0 & 43.6 & 382.0 & 29.0 & 42.5 \\
\hline $\begin{array}{l}\text { Untreated } \\
\text { area }\end{array}$ & 620 & 645.0 & - & 662 & - & 688 & - & 605 & - & 3220 \\
\hline
\end{tabular}

V = Vertimec, SMO = Super-Misrona oil, ME = Micro-Elements, LS = Liquid-Sulphur 
2. Evaluation of plant extracts:

Obtained data in Table (2) cleared that Oshar extract exhibited the highest mortality percentages of spider mites $68.7 \%$ followed by Black nightshade extract $62.7 \%$, while Neem extract was the lowest one $57.2 \%$. These results are agreement with those obtained by Sawires et al. (1995), Hassan et al. (2005), Gaber et al. (2004) and Hegab and AbdEl-Atty (2013). On the other hand Freedman et al. (1979) reported that Ethanol Oshar extract induced high mortality than Oshar extracted with hexane, petroleum ether and water, respectively.

\section{Effect of Utilizing the predatory} mite, $P$. persimilis on the population of spider mite, $T$. urticae on soybean plants:

Obtained results in Table (3) cleared that population of spider mites ranged between 136-164 of motile stages/20 leaflets for each plot A, B, C \& D before releasing the predatory mites, while the total number of mites for untreated area was 560 mites/80 leaflets before release.
As shown in Table (3) data revealed that the population of spider mites decreased slightly after releasing, whereas the average number of mites were $112,122,125 \& 132$ with reduction percentages of 24.0, 24.6, $17.9 \& 23.9$ a week after releasing for A, B, C \& D plots, respectively The reduction percentages of spider mites increased gradually to reach $56.5,44.8,63.3 \& 58.0 \%$ for the treated plots with average $55.70 \%$ a month later of release. This finding agreed with those obtained by Taha et al. (2001), Heikal et al. (2003) and Fouzy et al. (2006). After 8 weeks of release the reduction percentages of spider mites were $68.3,74.5,70.7 \& 72.6 \%$ with general mean $71.5 \%$, whereas the population abundance of spider mites were under threshold level infestation till the end of season. Finally, the foregoing results proved the possibility of controlling the spider mite, $T$. urticae in soybean fields by applying one release of the predatory mite, $P$. persimilis with rate of $15-20$ mites/plant.

Table (2): Number of mites and reduction \% of some plant extracts against $T$. urticae on soybean plants in Gharbia Governorate during the season 2017.

\begin{tabular}{|c|c|c|c|c|c|c|c|c|c|c|}
\hline \multirow{3}{*}{$\begin{array}{l}\text { Treatments } \\
\& \\
\text { application } \\
\text { rate I10 L. } \\
\text { water }\end{array}$} & \multirow{3}{*}{$\begin{array}{l}\text { No. of } \\
\text { mites } \\
\text { pre- } \\
\text { treatment }\end{array}$} & \multicolumn{8}{|c|}{$\begin{array}{l}\text { No. of mites } / 160 \text { sq. inches } \& \% \text { Reduction at } \\
\text { indicated days }\end{array}$} & \multirow{3}{*}{$\begin{array}{c}\text { Over } \\
\text { all } \\
\text { redu } \\
\text { ction } \\
\%\end{array}$} \\
\hline & & \multicolumn{2}{|c|}{3 days } & \multicolumn{2}{|c|}{7 days } & \multicolumn{2}{|c|}{14 days } & \multicolumn{2}{|c|}{21 days } & \\
\hline & & No. & $\%$ & No. & $\%$ & No. & $\%$ & No. & $\%$ & \\
\hline $\begin{array}{l}\text { Oshar } \\
50 \mathrm{ml}\end{array}$ & 614 & 125 & 80.1 & 185 & 71.8 & 248 & 63.6 & 245 & 59.1 & 68.7 \\
\hline $\begin{array}{c}\text { Black } \\
\text { nightshade } \\
50 \mathrm{ml}\end{array}$ & 562 & 152 & 74.0 & 192 & 68.0 & 254 & 59.3 & 277 & 49.5 & 62.7 \\
\hline $\begin{array}{l}\text { Neem } \\
50 \mathrm{ml}\end{array}$ & 666 & 216 & 68.8 & 270 & 62.0 & 315 & 57.4 & 386 & 40.6 & 57.2 \\
\hline $\begin{array}{l}\text { Untreated } \\
\text { area }\end{array}$ & 620 & 645 & - & 662 & - & 688 & - & 605 & - & - \\
\hline
\end{tabular}


Table (3): Efficiency of the predatory mite, Phytoseiulus persimilis against $T$. urticae on soybean plants in Gharbia Governorate during the 2017season.

\begin{tabular}{|c|c|c|c|c|c|c|c|c|c|c|}
\hline \multirow{3}{*}{$\begin{array}{l}\text { Sampling } \\
\text { date }\end{array}$} & \multicolumn{8}{|c|}{$\begin{array}{l}\text { No. of } T \text {. urticae / } 80 \text { leaflets after release of the } \\
\text { predatory mite and reduction percentages }\end{array}$} & \multirow{3}{*}{$\begin{array}{c}\text { Cont } \\
\text { rol }\end{array}$} & \multirow{3}{*}{$\begin{array}{c}\text { Over } \\
\text { all } \\
\text { Red } \\
\%\end{array}$} \\
\hline & \multicolumn{2}{|c|}{ A } & \multicolumn{2}{|c|}{ B } & \multicolumn{2}{|c|}{ C } & \multicolumn{2}{|c|}{ D } & & \\
\hline & No. & $\begin{array}{c}\text { Red } \\
\%\end{array}$ & No. & $\begin{array}{c}\text { Red } \\
\%\end{array}$ & No. & $\begin{array}{c}\text { Red } \\
\%\end{array}$ & No. & $\begin{array}{c}\text { Red } \\
\%\end{array}$ & & \\
\hline $\begin{array}{c}\text { July, } 5 \\
\text { pre-count of } \\
1^{\text {st }} \text { release }\end{array}$ & 136 & - & 153 & - & 144 & - & 164 & - & 560 & - \\
\hline $\begin{array}{l}\text { July, } 12 \\
\text { of } 1^{\text {st }} \text { release }\end{array}$ & 112 & 24.0 & 122 & 24.6 & 125 & 17.9 & 132 & 23.9 & 592 & 22.6 \\
\hline July, 19 & 96 & 35.0 & 102 & 38.0 & 105 & 32.2 & 110 & 37.6 & 608 & 44.5 \\
\hline July, 26 & 82 & 45.9 & 89 & 47.8 & 92 & 42.7 & 78 & 57.3 & 624 & 48.4 \\
\hline August, 2 & 65 & 56.5 & 74 & 44.8 & 58 & 63.3 & 61 & 58.0 & 615 & 55.7 \\
\hline August, 9 & 62 & 52.5 & 68 & 53.7 & 58 & 58.1 & 59 & 53.5 & 538 & 54.5 \\
\hline August, 16 & 54 & 58.8 & 50 & 66.1 & 52 & 62.6 & 48 & 69.6 & 540 & 64.3 \\
\hline August, 23 & 38 & 70.5 & 46 & 70.0 & 40 & 72.3 & 45 & 72.6 & 562 & 71.4 \\
\hline August, 27 & 42 & 68.3 & 38 & 74.5 & 41 & 70.7 & 44 & 72.6 & 545 & 71.5 \\
\hline Total & 687 & & 742 & & 715 & & 746 & & & \\
\hline Mean & 76.3 & & 82 & & 79.4 & & 83 & & & \\
\hline
\end{tabular}

No. = Number of spider mites.

Red\% = Reduction percentages.

4- Effect of different treatments on soybean yield parameters:

Obtained results in Table (4) revealed that soybean yield parameters were affected by different treatments, whereas the weight of fresh pods were high with using Micro-Elements 1.99 followed by Vertimec + ME 1.97, while the lowest one was Liquid-Sulphur 1.75. The weight of dry pods were high with using Vertimec alone 0.66 and low with Black nightshade extract 0.49 . In addition to, No. of pod/plant increasing with mixture of $\mathrm{V}+\mathrm{ME} 167$ pods, while the untreated area was $93 \mathrm{pod} / \mathrm{plant}$. Weight of 100 seeds was $13.6 \mathrm{~g}$, with Vertimec and 9.79 g with Black nightshade extract. The crop yield of soybean seeds was high $1875 \mathrm{Kg} /$ Feddan with ME followed by $\mathrm{V}$ $1827 \mathrm{Kg}$ and 1803 with using V + ME.

It is clear that using ME increasing the yield of crop in addition to minimizing the population of some sucking pests because of improved plant health, quantity and quality of pods and seeds. 
H. A. Taha, et al.,

Table (4): Some soybean yield parameters as a result of using alternative methods in controlling spider mites.

\begin{tabular}{|c|c|c|c|c|c|}
\hline Treatments & $\begin{array}{l}\text { weight fresh } \\
\text { pods } g\end{array}$ & $\begin{array}{l}\text { weight dry } \\
\text { pods g }\end{array}$ & $\begin{array}{c}\text { No. of } \\
\text { pod/plant }\end{array}$ & $\begin{array}{l}\text { weight } 100 \\
\text { seeds g }\end{array}$ & $\begin{array}{c}\text { yield /fed } \\
\mathbf{k g}\end{array}$ \\
\hline V+SMO & 1.96 & 0.54 & 143 & 10.36 & 1560 \\
\hline V+ME & 1.97 & 0.57 & 167 & 10.74 & 1803 \\
\hline v & 1.96 & 0.66 & 156 & 13.59 & 1827 \\
\hline SMO +ME & 1.76 & 0.60 & 159 & 12.16 & 1744 \\
\hline SMO & 1.84 & 0.56 & 106 & 10.67 & 1244 \\
\hline LS & 1.75 & 0.52 & 142 & 10.50 & 1655 \\
\hline ME & 1.99 & 0.57 & 164 & 11.18 & 1875 \\
\hline Oshar & 1.98 & 0.62 & 100 & 12.80 & 1264 \\
\hline Black night shade & 1.79 & 0.49 & 139 & 9.79 & 1195 \\
\hline Neem & 1.89 & 0.67 & 115 & 11.18 & 1100 \\
\hline Predatory mites & 1.93 & 0.59 & 189 & 11.34 & 1353 \\
\hline Untreated area & 1.03 & 0.42 & 93 & 8.22 & 890 \\
\hline Mean & 1.98 & 0.619 & 127.83 & 12.04 & 1591 \\
\hline Min. & 1.76 & 0.42 & 93 & 8.22 & 890 \\
\hline Max. & 1.99 & 0.67 & 189 & 13.59 & 1875 \\
\hline SD & 0.10 & 0.05 & 31 & 1.10 & 357 \\
\hline
\end{tabular}

V $=$ Vertimec. $\quad$ SMO $=$ Super - Misrona Oil. $M E=$ Micro - Elements. $\quad$ LS $=$ Liquid Sulpher.

\section{REFERENCES}

Baker, J. E. and W. A. Connel (1963). The morphology of the mouth parts and observation of feeding by spider mites on soybeans. Ann. Entomol. Soc. Am., 56: 733-736.

Botha, J. H., D. Ou-Plassis and F. J. Calitz (1994). Effect of acaricides on phytophagous mites and selected predators in apple orchards. J.
Southern Africa Soc. For Horticl. Sci., 1: 47-49.

Fouzy, M. M., K. M. El-Sayed and M. H. ElErksousy (2006). Evaluation of the predatory mite, Phytoseiulus persimilis (A.-H.) release on peach and almond trees at North Sinai Governorate to control the two spotted spider mite, Tetranychus urticae Koch. J. Agric. Res. 84 (b): 1811-1819. 
Freedman, B., J. Nowak and W. F. Kwolek (1979). A bioassay for plant derived pest control agent using the European comborer. J. Econ. Entomol., 72: 4554.

Gaber, W. M., Fatma K. Khidr and A.M. Hegab (2004). Evaluation of Oshar crude plant extract as a rodenticide under laboratory and field conditions. Zagazig J. Agric. Res., 31 (4A): 6071616.

Hendrson, C.F. and E.W. Tilton (1955). Test with acaricides against the brown wheat mite., J. Econ Entomol., 48 : 157-161.

Hassan, M. F., Z. R. Soliman and S. D. Shery (2005). Evaluation of some plant extracts against the two spotted spider mite, Tetranychus urticae Koch (Acari : Tetranychidae). J. Agric. Sci. Mansoura Univ., 30 (1): 611-621.

Hegab, M.E.M. and S.E. Abd-El-Atty (2013). Biological efficacy of three commercial formulations of plant extracts on spiny Boll worm Earias insulana (Boisd) under laboratory conditions. Egypt, J. Agric. Res.91(3):849-858.

Heikal, I. H., G. A. Ibrahim, K. M. El-Sayed and M. S. El-Ghobashy (2003).
Biological control of Tetranychus urticae Koch in strawberry open fields and greenhouses by releasing Phytoseiulus macropilis (Banks) (Acari : Tetranychidae \& Phytoseiidae). Egypt. J. Agric. Res., 81 (4): 1595-1608.

Masis, C. and H. Aguilar (1990). Control of mite, Tetranychus urticae Koch in strawberries in Costa Rica. Manage Integrate Dep. Plagas, 17: 5-7.

Omar, H. I. H., M. El-Bessony, H. ElMaghraby and M. El-Khawalka (2000). Effect of abamectin compared with different compounds on the two spotted spider mite and two insect leafminers. J. Agric. Sci., Mansoura Univ., 25 (12): 8089-80966.

Sawires, Z. R., N. G. Iskander and M. A. Ahmed (1995). Toxic action of some plant extracts against Tetranychus urticae Koch. Proc. $6^{\text {th }}$ Nat. Conf. Pest \& Dis. Of Vegetables \& Fruites in Egypt, P. 165-177.

Taha, H. A., M. A. Ahmed and Ahlam A. Younes (2002). Induced resistance to spider mite, Tetranychus urticae Koch infection of cotton and soybean plants. J. Agric. Sci., Mansoura Univ., 27 (1): 1625-1636. 


\section{الطرق البديلة في مكافحة الأكاروس العنكبوتي ذي البقعتين Tetranychus urticae Koch ( Acari : Tetranychidae )}

حسن علي أحمد طه، أحمد ابراهيم عامر، هبه محمد نصر

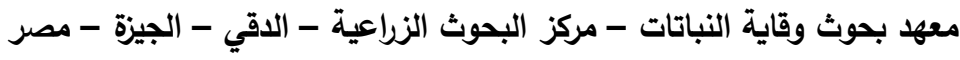

الملخص العربي

يعتبر فول الصويا من المحاصيل البقولية الهامة حيث يلقي اهتماما دوليا نظراً لإحتواء بذوره علي نسبة عالية من

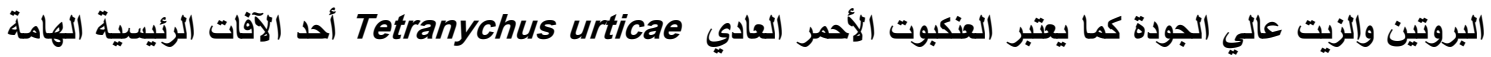

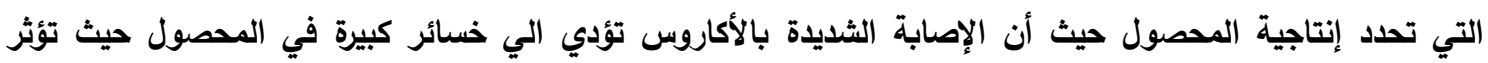
الإصابة علي حجم البذرة ومحتواها من الزيت والبروتين.

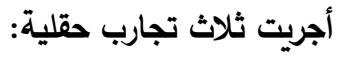

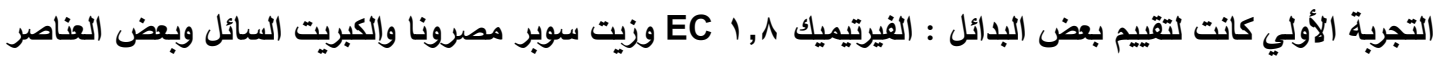
الصغري منفردة ومخلوطة في مكافحة العنكبوت الأحمر العادي علي فول الصويا.

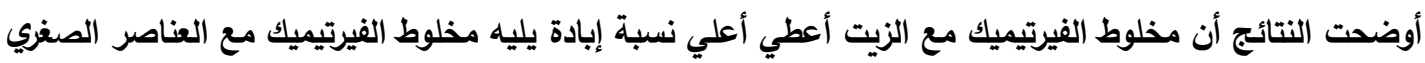
وأقلها العناصر الصغري منفردة . والتجربة الثانية لتقييم بعض المستخلصات النباتية: العثار - ثمار عنب الديب النيئة والنيم وقد أعطي مستخلص

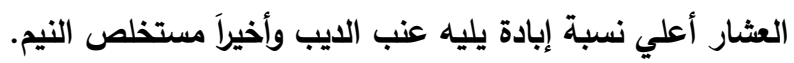
أما التجربة الثالثة فكانت تقييم المفترس الأكاروسي

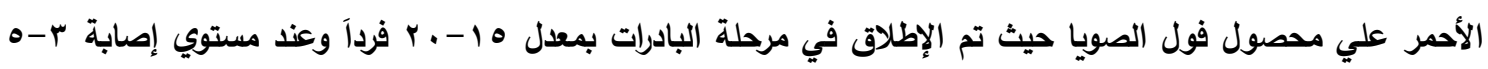

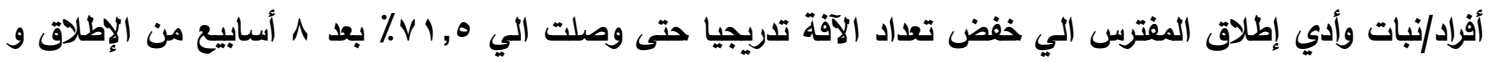
ظل تعداد الآفة أقل من الحد الإقتصادي الحرج حتي نهاية المحصول. وبتقييم المعاملات السابقة علي إنتاجية المحصول من القرون الخضراء والجافة وعدد القرون ووزن الحبوب و إنتاجية

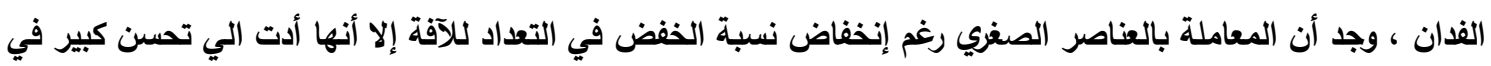
حالة النبات الصحية وبالتالي تحسن في إنتاجية المحصول عن المعاملات الآخري. 
Alternative methods in the control of the two spotted spider mite, ............... 
H. A. Taha, et al., 
Alternative methods in the control of the two spotted spider mite, ............... 